УДК: 811.163.41'374

811.163.41'28

https://doi.org/10.18485/kij.2017.64.1_2.2

ПРВОСЛАВ Т. РАДИТ *

Универзитет у Београду

Филолошки факултет
Оригинални научни рад

Примљен: 25.02.2017.

Прихваћен: 15.04.2017.

\title{
О ТЗВ. ВЕЛИКОМ РЕЧНИКУ САНУ И НЕКИМ ДРУГИМ ПИТАЬИМА
}

М. Московљевићу (1884-1968)

\begin{abstract}
Прилог је у првом делу посвећен једном терминолошком питању из области србистике, заправо месту термина „штокавски дијалекат” (/ „штокавско нар(j)ечје”) у науци о српском језику. То је, у суштини, једно од основних питања србистичке науке, иако стицајем различитих околности прилично касно долази на ред. Без јасних одговора на питање о месту и сврсисходности термина „штокавски” нема ни одговора на низ других суштинских питања, која се крећу у распону од основног омеђења српског језичког простора до могућности доследне употребе лингвонима сриски језик у савременој језичкој употреби. Та питања се често тичу и самог тумачења назива наших језичких издања, како ововремених (нпр. Речника САНУ) тако оних пређашњих, те се понекад намеће потреба њиховог поновног лингвистичког вредновања. Том питању посвећен је други део прилога.
\end{abstract}

Кључне речи: српски језик, терминологија, лексикографија, „српскохрватски језик”, „штокавски дијалекат”, Речник САНУ.

Крајем прошле године, у оквиру културне манифестације Сачувајмо српски језик, појавио се у Политици чланак научног саветника Института за српски језик Српске академије наука и уметности, др Стане Ристић, под насловом Штокавске збирке речи (Ристић 2016). За поднаслов чланка извучена је реченица: Грађа Речника САНУ чини највећу и најпотпунију збирку лексике савременог српског језика. Овај чланак, који је настао из пера тадашњег уредника Речника САНУ и председника његовог Уређивачког одбора, није толико разлог колико повод да се у овом прилогу осврнем на поједина места из иначе лексикографски стручног и садржајног текста који читаоцима нуди сажет преглед настанка и развоја овог речника на онолико простора колико је то у новинским чланцима овога типа уобичајено.

*prvoslavr@yahoo.com 
Задржаћу се укратко на двема србистичким тематским целинама које завређују пажњу у радовима овакве тематике: првој, општијој, добрим делом посвећеној појединим лингвистичким терминима, и другој непосредније везаној за сам Речник српскохрватског књижевног и народног језика САНУ (надаље: PCAHУ).

\section{1. У виртуелној лингвистичкој стварности: Од српског језика до штокавског дијалекта $\leftrightarrow$ од штокавског језика до српског дијалекта}

На терминолошком плану, данас већ и по некој врсти новоуспостављене традиције, у србистици се, и то обично паралелно, користе атрибути сриски и штокавски. И аутор поменутог чланка, др Стана Ристић, уз лингвоним српски паралелно употребљава и термин штокавски, иако изостаје појашњење у каквом су појмовно-значењском односу ове лексеме у ауторовом тексту. У наслову ауторовог чланка стоји Штокавске збирке речи (мисли се на оне које су ушле у РСАНУ), а термин штокавски јавља се и код помињања „целокупног штокавског дијалекта”, као и „подручја штокавског дијалекта”. На другој страни, термин српски помиње се у поднаслову, у оквиру израза: „збирка лексике савременог српског језика", и надаље на више места: „различити крајеви у којима се говори српски језик”, „различити периоди српског језика”, те „лексички фонд српског књижевног и народног језика". ${ }^{1}$ Рекло би се, на први поглед, да се у тексту термини српски и штокавски употребљавају мање-више синонимно (на шта као да упућује већ наслов са својим поднасловом), но ипак с тежњом да се термин штокавски веже за дијасистем (,штокавски дијалекат”), а српски, поред општег значења, и за нормативни систем („модерни српски књижевни језик”, „савремени српски језик"). ${ }^{2}$ Уочљиво је, ипак, да у оваквом приступу у тексту изостаје термин српски дијалекти, као и српске збирке речи, а уместо квалификације срnски овде им је дата квалификација штокавски. Зашто у ауторовом тексту лингвистички термин српски нема своје универзално право терминолошке употребе, као што га имају други језици, укључујући право и на своје, српске дијалекте (нпр. српски језик - српски дијалекти - српске збирке речи итд.)? ${ }^{3} \mathrm{Jеp,} \mathrm{ако} \mathrm{се} \mathrm{под}$ дијалектом углавном подразумева регионални варијетет неког језика, како је могуће да српски, ако се он прихвата као језик, нема своје дијалекте? И ком то, уосталом, језику припада штокавски дијалекат?

\footnotetext{
${ }^{1}$ Исп. и ,„развој и култивација модерног српског књижевног језика”, ,,ексички и терминолошки фонд савременог српског језика" и др.

${ }^{2}$ Изузетак је, у неку руку, реченица у којој се помињу „различити крајеви у којима се говори српски језик".

${ }^{3}$ Подсетимо, последњих година, након распада парадигме тзв. српскохрватског језика, појавила се књига М. Окуке под насловом Српски дијалекти (СКД Просвјета, Загреб 2008), затим П. Ивића, Српски дијалекти и њихова класификација (Сремски Карловци - Нови Сад, 2009) и др.
} 
Видели смо, међутим, да аутор штокавски дијалекат, ипак, имплицитно посматра кроз територијални домет српског језика и на једном месту бележи да РСАНУ укључује грађу „савременог српског језика”, која, штавише, по територијалном параметру „обухвата читаво подручје штокавско[г] дијалекта који је у основи српског језика" (ово, додуше, дато у загради). Шта то значи да је читав штокавски дијалекат у основи српског језика - аутор није појаснио. ${ }^{4}$ Ако је мислио на то да поред „штокавског” и неки други „дијалекти”, на пример тзв. чакавски или кајкавски, у одређеној мери учествују у корпусу српског дијасистема, такав приступ није смислен јер ови идиоми немају везе са српским језиком, ${ }^{5}$ као што с њим нема везе ни бугарски родопски дијалекат или словеначки корушки. Ако је, пак, аутор мислио на тзв. торлачки (у нашој терминологији призренско-тимочки) дијалекат, као још један српски дијалекат, издвајајући га из корпуса штокавског те га на одређени начин и супротстављајући њему, онда је то изван методологије, па и традиције српске лингвистичке науке. Такав приступ би, у ствари, сугерисао недовољно српски идентитет призренско-тимочке дијалекатске области. Он је већ виђен у филологијама суседних земаља (нпр. хрватској, бугарској), и не може му се оспорити политички интерес тамошњих филолошких кругова. Вероватно је управо с тог гледишта поодавно критикован покушај једног броја лингвиста „да исконструишу четврти српскохрватски дијалекат” (Будимир 1969: 165).

На другој страни, ако аутор није мислио на учешће (у духу његове терминологије) „не-штокавских” дијалеката у дијасистему српског језика, и не издвајајући, притом, призренско-тимочки дијалекат из корпуса штокавског система, онда се и ова његова тврдња може тумачити у смислу (макар претежно) синонимног односа између лингвистичких појмова српски и штокавски, односно у смислу штокавског карактера српског језика (или можда и обрнуто), ${ }^{6}$ колико год то таутолошки звучало. Но, то није крај логичко-мисаоним неравнинама у приступима овога типа. Јер, ако се српски поистовећује с једним дијалектом, тзв. штокавским, онда уводимо необичан и несвакидашњи лингвистички конструкт којим се замагљује граница између језика и дијалекта, па и међу језицима и дијалектима, а термин српски језик потискује термином итокавски дијалекат (исп. фус. 13). Могуће је и да смо онда на терену трагања за језиком чији је српски фактички тек један део („дијалекат”), и могли бисмо у овоме препознати ауторово, можда и ненамерно, истрајавање на парадигми српскохрватског језика, те његове штокавище која је данас у основи низа новостворених (/ новообзнањених) језичких

${ }^{4}$ Из овога није јасно ни да ли се мисли на српски књижевни језик, што у том случају не одговара истини, или на дијасистем српског језика

${ }^{5}$ Нити по језичком систему нити по уделу припадника српске националности (којих тамо нема), - ови дијалекти не припадају српском језичком простору.

${ }^{6}$ Тако је у време владавине парадигме тзв. српскохрватског језика П. Ивић написао Дијалектологију српскохрватског језика (Нови Сад, 1956), али усредсредивши се на српски језички простор, због чега у поднаслову књиге стоји: Увод у штокавско наречје. Међутим, потоње одбацивање ове парадигме учинило је у србистици термин штокавски сувишним, па и штетним (исп. Радић 2008: 136). 
стандарда. ${ }^{7}$ То би онда значило негирање самосвојности српског језика, заправо, само формално прихватање лингвонима српски језик (исп. 2), а суштински истрајавање на парадигми српскохрватског језика (са тзв. штокавским, чакавским и кајкавским дијалектом у свом саставу), - или још горе, слободну мешавину оба приступа. Јер, само се на тај начин итокавица може једном узимати за дијалекат српског језика (или српски дијалекат), а други пут фактички за надјезик кога чини више савремених језика, и чији, дакле, тек један део припада српском. А управо су ауторов наслов и поднаслов тако повезани да могу сугерисати и то: подређеност српског језика штокавском „надјезику”.

Овакве нејасноће у приступу, које су одлика низа наших лингвистичких текстова ове тематике, резултат су, у ствари, несналажења у лингвистичкој материји везаној за основна идентитетска питања српског језика и његовог територијалног простирања. Те појаве нису новијег датума и вероватно су и део идентитетских питања везаних за сам српски народ. Српско релативно рано одступање од караџићевско-миклошичевске лингвистичке парадигме о тзв. штокавици (територије Србије, Босне, Херцеговине, Црне Горе, Славоније, Далмације и др.) као српском језику, у замену за политику србохрватства и југословенства, устоличило је научнополитичку парадигму заједничког српскохрватског / хрватскосрпског језика (В. Јагић, А. Белић и др.), на чему је посебно инсистирала југословенска комунистичка власт непосредно након Другог светског рата (в. фус. 7). Распад СФР Југославије крајем прошлог столећа и наставак стварања и дорађивања језичких стандарда на етничким просторима српског језика оставио је српске филологе збуњене и дезоријентисане. Враћање Караџићевој лингвистичкој парадигми чини им се сада прекасно, можда назадно, или у садашњем стању српског духа сувише национално и, у глобалистичкој терминологији речено, „политички некоректно”. ${ }^{8}$ На другој страни, то се може чинити и конфликтним са становишта проевропских стремљења србијанске политичке елите. Зато се, изгледа, као нека врста компромисног научнополитичког решења нуди званично постојање српског језика, што, уосталом, налаже и формално-правно (ре)утемељење овог лингвонима, ${ }^{9}$ али у исто време и „његовог” штокавског

\footnotetext{
${ }^{7}$ У другој фази титоистичке владавине у СФР Југославији активно се радило на изградњи републичких језичких стандарда под плаштом заједничког „српскохрватског” књижевног језика, али су политички замеци ових процеса много старији. У том циљу се и из појединих западних центара овде поодавно подупире обликовање постјугословенских језичких стандарда као наследника „српскохрватског” језика - од хрватског и бошњачког (с тежњом да овај последњи буде терминолошки општеприхваћен као босански), преко црногорског до српског (с тежњом да српски буде, заправо, србијански). Данас је код твораца тих стандарда, с изузетком српских, видљива и тежња да се за стандардизацијску основу, ипак, пронађу посебни, изворни(ји) дијалекатски идиоми.

${ }^{8}$ Пандан за „политичку коректност” била је у комунистичко време ,друштвенополитичка подобност". И један и други термин подразумевају изгледа обавезу грађана да прате званичну политику и буду део владајуће политичке парадигме, што се, рекло би се, посебно очекује од интелектуалаца. Данас се недовољно указује на то да спровођење „политичке коректности” у корист једних понекад значи „политичку некоректност” за друге.

${ }^{9}$ По Уставу Р. Србије (чл. 10), у службеној употреби је „српски језик” (Службени гласник РС 98/2006).
} 
дијалекта, као остатка пређашње парадигме. Међутим, истрајавањем на термину штокавски, намерно или не, подрива се па и негира свест о постојању српског језика, а свакако се тиме збуњујуће делује на све оне који би желели да из ове важне друштвене области иоле нешто разумеју. ${ }^{10}$ Из тог разлога један број писаца наших новијих школских граматика (нпр. Ломпар 2012, Кликовац / Николић 2014), представљајући српски дијалекатски простор, сасвим оправдано искључује из употребе термин цтокавски. То као да најављује боља времена у српској филологији, и не само ту.

\section{2. Речничко дело између науке и политике: Нека запажања о Великом (,штокавском”) речнику САНУ}

За Академијин Речник, који се често назива и великим (додуше, без терминолошке опозиције према неком другом, мањем речнику), заиста се од почетка планирало да по много чему буде велики речник, али је он врло рано почео доживљавати различите концепцијске ударе, намерне или не, који су отежавали његову израду. Не чуди што се данас име овог речника већ почиње симболички везивати и за нешто посве друго од почетних идеја везаних за њега. Идеја о издавању Речника народнога кюижевног језика српског званично је потекла од Ст. Новаковића (1888), српског филолога, историчара књижевности, дипломате и председника Српске краљевске академије. ${ }^{11}$ Ово је требало, дакле, да буде речник савременог српског књижевног језика (који почива на одређеном типу српских народних говора), јер је један други речник, својим знатним делом такође српски, Даничићев загребачки речник (Rječnik hrvatskoga ili srpskoga jezika, Zagreb 1880-1976), конципиран као историјски речник, већ добрано имао покрити област српских дијалеката, као и старе српске књижевности и писмености. С таквом концепцијом Академијиног речника се, међутим, од самог почетка није слагао тада велики научни ауторитет у области славистике, Хрват Ватрослав Јагић, који се издавао за југословенски оријентисаног интелектуалца и званично заговарао српско-хрватско језичко јединство. Он је сматрао да србијанска страна „одвећ рано” приступа нормативистичким пословима ове врсте, те да је најбоље да остане на пословима скупљања дијалекатског материјала, пре свега у Србији (!), што је и отворено изнео у писму упућеном Новаковићу (према Добраши-

${ }^{10}$ На тај магловит међуоднос појмова српски и штокавски већ се привикла шира друштвена заједница образованих људи. У једном ТВ квизу (Потера, РТС 1, 7. XI 2015) на питање Које је наречје у основи српског књижевног језика - као тачан намењен је одговор: итокавско (?!). Такве нејасноће везане за однос српски - итокавски прате и већину наших школских граматика српског језика, готово редовно се преливајући и у тестове српског језика за различите врсте пријемних испита, укључујући и оне који се раде приликом уписа на филолошке (/ филозофске) факултете. „Тешка је то ствар кад се човјеку из дјетињства штогод у памет уврти!”, написаће В. Караџић у једном писму J. Копитару.

${ }^{11}$ Новаковић није поменут у чланку др Стане Ристић, с чим би се, верујем, и он данас сложио. 
новић 1995: 358). ${ }^{12}$ Иако је, ипак, тешко овде не прозрети Јагићев стратешки приступ везан за будуће филолошке односе између Срба и Хрвата („српског” и „хрватског” језика у његовој визури), није јасно да ли је и колико Јагићева интервенција била разлог одуговлачењу српских послова на издавању првих томова овога дела. Но, тај разлог су свакако морали бити ратови (Балкански, Први светски рат, Други светски рат), тешко економско стање у земљи, те и српска кадровска неспремност за обимне лексикографске послове ове врсте. Још један чинилац убрзано је и паралелно с овим узимао свој данак - југословенска идеологија, која је као и свака идеологија језик сматрала једним од својих главних упоришта. ${ }^{13}$ Њен главни промотер на српској страни био је у обема Југославијама Александар Белић, не случајно Јагићев сарадник и велики поклоник Јагићева дела (исп. Радић 2012). Белић се већ од почетка XX столећа нашао међу главним српским (тачније: југословенским) лингвистима и рад на једном оваквом речнику није се могао замислити без њега, нарочито од 1920. године (исп. РСАНУ I: XVI), а то је период када су и Јагић и Маретић у животу. Оваква клима наставила се и у потоњем периоду. Посебно је комунистичко југословенско руководство пуно рачунало на Белићеву ерудицију, међународну репутацију и способности различите врсте, а знало је и како да провереним методама обезбеди његову пуну сарадњу (исп. Marković 2005). То, изгледа, и није много било у супротности с Белићевим карактерним профилом.

Већ након Другог светског рата, 1947. године, Белић се, као тадашњи (и пређашњи) председник Академије, нашао на челу новооснованог Института за српски језик (од 1958. год. Институт за српскохрватски језик). Ову институцију је чекало коначно издавање првих томова речника, јер прошло је било више од пола века од како се дошло на идеју о његовом издавању, а и први материјали су већ били прошли обраду. Но, Српска академија није била у милости Брозове комунистичке власти и на издавање првог тома морало се још чекати. У међувремену ће морати да прође и Новосадски договор (1954), организован од стране политичких структура, где су приведени српски учесници углавном били у дефанзиви (в. Милосављевић / Суботић 2014: 321-439), а на коме се дискутовало и о називу језика. Тада је званично устоличен назив српскохрватски / хрватскосрпски, што је прихватила (и) српска страна потврдивши језичко ( $\rightarrow$ политичко) јединство Срба и Хрвата. ${ }^{14}$ Коначно, питање назива речника, већ поодавно

${ }^{12}$ И хрватски филолог Т. Маретић, у вези с објављеном првом огледном свеском речниковом (сада под насловом: Српски речник књижевнога и народнога језика, Београд 1913), замера овом издању, између осталог, то што се у називу речника не налази хрватско име (према РСАНУ I: XII). А. Белић ће у Уводу првог тома речника прихватити ову Маретићеву критику (Исто, в. даље).

${ }^{13}$ На то указује и чињеница да је управо српски језик, као језик средњојужнословенског поднебља, од половине XIX столећа до наших дана главни предмет низа политичких декларација, иницираних углавном изван оквира српског народа. Неке од њих зато и не укључују питање назива језика о коме се изјашњавају.

${ }^{14}$ У оквиру више објављених речничких огледних свезака, појавиће се пред Новосадски договор Огледна свеска Речника српскохрватског језика (1953). У периоду од само неколико година и овај наслов ће бити промењен. 
проблематизовано, решиће се сада називом Речник српскохрватског књижевног и народног језика, али је било и других проблема који су поново одложили издавање првог тома, те се он коначно појавио тек 1959. године. Међу тим новијим разлозима за кашњење била је и недовољност лексике из дела хрватских писаца, али и делатности комунистичког покрета, дакле из оног периода који је фактички тек почињао да живи међу Србима. О томе сазнајемо из Увода (РСАНУ I: VII-XXVI) датог уз први том, датираног још септембром 1955. године, који потписује Белић као главни уредник, где се као разлог за кашњење у издавању првог тома износи „црпење грађе из језика хрватских писаца”, али и „нарочито црпење грађе из дела илегалне литературе предратног времена” (Исто: XXII). Након пар страна Белић ће осетити потребу да понови и нагласи: „Нарочита је пажња поклоњена хрватским писцима (одмах 1948 г.) и изнесена потреба да се број њихових дела знатно попуни [...], затим да се унесе грађа из литературе Народноослободилачке борбе и послератног периода" (Исто: XXV). Наслов речника правдан је ставом да он обухвата „речничко благо Срба и Хрвата”, те представља „речник заједничког језика њихове културе и књижевности” (Исто: VII).

Биће корисно за даља истраживања у вези с настанком овог речника утврдити колико је у концепцију Речника уграђен комунистички реваншизам према српској страни, ${ }^{15}$ те спровођено и својеврсно понижавање српске науке и њених научника. Анализа заступљености лексикографских извора за Речник САНУ у овоме такође може пуно помоћи, а о томе последњих деценија већ постоје поједине оцене дате из редова србијанских књижевника (нпр. Михаиловић 2006: 22-26, 38-44). Није искључено, тако, да је постојала намера да Загрепчани (иначе кајкавци родом), који су писали на српском („српскохрватском”) као њима страном језику, буду више заступљени у овом речнику (дефакто речнику српскога језика) од самих српских писаца. ${ }^{16}$ Иако би подробнија анализа дала прецизније резултате (и када је реч о првом и када је реч о потоњим томовима), извори наведени уз први том речника показују, на пример, да је К. Ш. Ђалски заступљен са седамнаест књижевних дела, А. Шеноа с петнаест, М. Крлежа с десет, А. Цесарец са седам итд. Од Крлеже је тек нешто мало боље заступљен српски писац П. П. Његош, с једанаест дела, а слабије од Крлеже стоји И. Андрић, с осам, који за разлику од Крлеже, опште је познато, није био Брозов миљеник. Књижевници комунисти, учесници у тзв. нароодноослободилачкој борби, или они који су били присталице овог покрета, били су солидно заступљени (нпр. хрватски песник В. Назор с деветнаест наслова), макар били и Срби (нпр. Б. Ћопић с дванаест, В. Петровић с једанаест). Тај повлашћени статус односи се и на идеологе и симпатизере социјалистичког покрета из пређашњих времена, те ватрене заговорнике српско-хрватског јединства, међу којима је било доста

\footnotetext{
${ }^{15}$ Опште је познато да је однос комунистичке власти према Србији, нарочито у периоду непосредно после Другог светског рата, био окупаторске природе. То не треба да чуди ако се зна да је на челу ове власти био хрватски комуниста и аустријски каплар из Првог светског рата.

${ }^{16}$ Можда је ово требало да буде и својеврстан одговор на Даничићево неукључивање кајкавског материјала у загребачки Rječnik hrvatskoga ili srpskoga jezika, с чим се Јагић није слагао.
} 
Срба. Тако је Ј. Скерлић заступљен с чак деветнаест наслова. Овакав приступ речничким изворима очито је био део владајуће политичке технологије, те ће њиме бити обележени и други издавачки подухвати тога времена, лексикони, енциклопедије и сл. Тако, у тадашњем Jugoslovenskom književnom leksikonu Матице српске (JKL) Крлежи је такође дато више места него Андрићу, иако је Андрић тада већ био нобеловац, једини с Балкана. На лингвистичком плану, пак, хрватски лингвиста Д. Брозовић, који ће у време распада СФРЈ најављивати да ће се Хрватска бранити на Дрини, заступљен је у овом лексикону, док српског лингвисте П. Ивића, који с комунистичким властима никада није био у добрим односима, у лексикону нема.

Може се, дакле, претпоставити да је удео комунистичких кадрова у главним пословима око издавања Академијиног речника компромитовао овај велики српски културно-национални подухват и донео му доста штете. Он је, ипак, заједно с Белићевим уредничким радом, представљен као (додуше, будуће) врхунско и готово култно лексикографско дело које се не коментарише, и безмало да је тако остало до данашњих времена. Једини који се усудио да критички оцени новоиздати том био је Милош Московљевић, још од 1933. године учесник на овом лексикографском послу и једно време његов редактор (исп. PCAНУ I: XVII). ${ }^{17}$ Његов критички осврт појавио се тек четири године након објављивања првог тома, и то после Белићеве смрти (1960). Московљевић на почетку своје критике образлаже намеру да прикаже дело јер се „досад нико од стручњака није осврнуо на њега" (Московљевић 1963: 241), те да та ћутња стручних и књижевних часописа, штампе, радија и др., није у сагласности с читавим веком ишчекивања „савременог књижевног речника” (Исто). ${ }^{18}$ Аутор овде пише о проблематичној природи речника и самом његовом називу, погрешним одлукама да он буде и дијалекатски (утолико пре што је, по аутору, планско и систематско скупљање лексичке грађе после Новаковића било напуштено), о недостатку јасних критерија приликом избора грађе, о погрешним акцентима, преширокој употреби глаголских изведеница са суфиксима страног порекла (посебно, чини се, у вези с -ира), погрешном поистовећењу одредничког пара Алба́наи = Арба̀нас (/ Шиптар) и другим пропустима који указују на помањкање професионалности у раду Белићевог лексикографског тима.

Московљевићев прилично негативан приказ широког спектра открио је у позадини и ауторов „дисидентски” наступ у вези с низом питања, што се мог-

${ }^{17}$ М. Московљевић (1884-1968) је био Белићев студент, гимназијски професор и професор Више педагошке школе у Београду, полиглота, преводилац с руског и лексикограф. Био је учесник (добровољац) у Првом светском рату и носилац Албанске споменице, народни посланик у Краљевини Југославији, те једно време министар у комунистичкој Југославији и дипломата. Одбранивши докторски рад Акценатски систем поцерског говора (1928), постао је први доктор филологије на Београдском универзитету.

${ }^{18}$ Питање је да ли се таква ћутња стручних кругова може тумачити страхом од диктаторског југословенског режима, или се у вези с тим и сам речник доживљавао као пројекат комунистичког окупатора (в. фус. 15). 
ло препознати већ у његовим наступима на Новосадском договору. ${ }^{19}$ Мада се експлицитно не противи парадими „српскохрватског” језика, што се и не може очекивати у то време (в. фус. 15), он налази прилику да у приказу помене чувену (тачније: нечувену) тврдњу из Броз-Ивековићевог Rječnika hrvatskoga jezika (1901), „за који у предговору Ивековић каже да би се могао звати и 'рјечник Српскога језика', ${ }^{20}$ али се зове 'рјечник Хрватскога језика' јер су га списали и на свијет издали Хрвати" (Исто: 241). Овакав приказ првог тома Речника САН, дела које је требало да буде симбол српско-хрватског (и југословенског) јединства, а који приказивач потписује „На Видовдан, 1962. године”, најављивао је отворенији сукоб српске науке и Брозове антисрпске политике. И само рангирање овога приказа у часопису о томе доста речито говори: Објављен је у поглављу Оцене и прикази, на последњем месту, после приказа фототипског издања Славено-сербског магазина (Ј. Деретић) и књиге К. Георгијевића о Шеноиним погледима на књижевност (М. Живанчевић). Московљевићев покушај да након појаве првог тома Речника укаже на његове недостатке није изгледа имао никакву тежину. Штавише, он се завршио прилично лоше, пре свега по самог аутора, у складу с временом у којем се живело и методологијом којом се владало. ${ }^{21}$

Какве су намере комунистичке власти на плану лингвистичког профилисања овог речника, дакле и језичке политике у односу Срба и Хрвата, откриће се тек темељном анализом речника и праћењем његове уређивачке политике кроз време. Они ће показати и да ли је и колико речник стварно бринуо о јединству тзв. српскохрватског језика (и каквој врсти јединства), и шта је све било у позадини овог великог српског лексикографског подухвата који су преузели комунисти у његовој најзначајнијој, почетној издавачкој фази. Истраживања ће вероватно показати и како тачно треба разумети „стални напор да се избалансира грађа према различитим критеријумима како би се што целовитије представио лексички фонд српског књижевног и народног језика”, како пише др Стана Ристић. Ево једног ситног, давнашњег лексикографског детаља који је такође можда представљао једну врсту „балансирања”, но не у корист србистике као науке. У РСАНУ су, на пример, као деминутиви од до / добл дате изведенице долче и до̀чић (4. том, 1966). Прва је обележена као покрајинска реч, није дат пример

\footnotetext{
${ }^{19}$ У вези с низом тема Московљевић је, мање или више отворено, био на линији караџићевско-миклошичевског филолошког учења о „штокавици” као српском језику, те ће у једном од својих новосадских излагања истаћи и ово: „Хрвати нису раније имали овај данашњи књижевни језик, јер у већини нису њиме ни говорили. Кајкавцима и чакавцима Вуков речник је послужио за то да науче како треба писати штокавско-ијекавским дијалектом” (Милосављевић / Суботић 2014: 404). То показује да је и у најтежим временима по српски народ било српских интелектуалаца који су уважавали језичку реалност и следили Караџићево учење, одбијајући да се приклоне јагићевско-белићевском филолошком програму.

${ }^{20}$ Речник је настао на српском лексичком материјалу (В. Караџић, Ђ. Даничић, П. П. Његош, М. Ђ. Милићевић).

${ }^{21}$ Московљевић је умро 1968. год., управо у по много чему узбурканој југословенској години. Следеће године (2018) навршава се, дакле, педесет година од Московљевићеве смрти. То би могла бити прилика да установе и стручњаци који се баве српским језиком, посебно лексикографијом, покушају реално вредновати Московљевићев рад у овој области.
} 
употребе, а као извор наведена је дијалекатска збирка речи с југа Србије (Т. Димитријевић, Збирка речи из Врања). Уз други пример наведене су две потврде, обе из хрватских писаних извора, и то релативно старијих (Arkiv za povjestnicu jugoslavensku, Zagreb 1851-1872 и E. Kumičić, Zagreb 1910). Како треба разумети овакво српско-хрватско лексикографско „балансирање”? Да ли и овако:

1. Долче се може узети за српску реч, а долчић за хрватску (тј. -че је у категорији предмета српска особина, док је -чић хрватска)?

2. Српско -че је покрајинско (дијалекатско), а хрватско -чић је (одвајкада) књижевнојезичко?

3. Заједничка норма („,српскохрватска”) у овом творбеном типу захтева -чић и та норма је, заправо, хрватска?

Иако можда тек стидљиво изнета у лексикографским методама овог речника, теза о српском као делу (у суштини) хрватског језичког комплекса не би била нова хрватска лингвистичка теза. С њом се Срби суочавају већ од XIX столећа, ${ }^{22}$ а такви приступи језичком односу српско - хрватско (рачунајући и управо наведен детаљ о односу суфикса -че и -чић) могли су се препознати и у језичким документима (анкетама) који су претходили Новосадском договору (исп. Милосављевић / Суботић 2014: 187). Нажалост, чланак др Стане Ристић, на који сам овде скренуо пажњу, указује на то да српска филолошка елита ни данас нема јасан, а понајмање усаглашен став о тим питањима.

Рекло би се, дакле, да србијанска јавност још увек чека неке од одговора у вези с Академијиним речником, утолико пре што овај речник сада броји деветнаест томова (до: оцат-петогласник). ${ }^{23}$ Овдашњу културну и научну јавност би, на пример, и данас могло занимати колико су Московљевићеве критичке напомене биле оправдане, а неке можда и данас актуалне. Могло би је занимати како је дошло до тога да се РСАНУ временом још више приближи Јагићевој концепцији дијалекатског речника, па и то уз крупне методолошке пропусте који се тичу представљања дијалекатске грађе (исп. Стијовић 2000). Могла би је занимати и даља судбина овог речника, његов коначан обим, степен посвећеност његовој изради и темпо израде, посебно с обзиром на чињеницу да се од идеје један том годишье одустало пре него што је речник заживео. ${ }^{24}$ Ту је, најзад, иако не мање важно, питање дугогодишњег рекламирања хрватског имена у на-

${ }^{22}$ Можда управо добрим делом због српске оданости термину итокавски, у последње време ће и немачки социолингвист Л. Аубургер, по принципу просте замене теза, у својој књизи (1999) написати како је варварски српски народ Хрватима у ХІХ ст. отео и језик (према Okuka 2006: 291).

${ }^{23}$ Повољна је чињеница што је у вези с Речником у последње време међу србијанским лингвистима, поред поновног отварања појединих питања, отпочето са сучељавањем и систематизовањем предлога који се тичу будућности овог издавачког подухвата (исп. Пипер 2016: 14-16).

${ }^{24}$ У међувремену су већ два значајна речника српског језика угледала светло дана, вишетомни Речник Матице српске (1967-1976) и Николићев једнотомник (2007), такође у Матичином издању. 
зиву једног речника Српске академије (на рачун пореских обвезника Србије) - и након распада некада заједничке нам државе и званичног повлачења термина „српскохрватски” језик на читавом простору бивше СФРЈ (исп. фус. 22). Је ли реч о добро утабаној филолошкој навици, југоносталгији, остављању одшкринутих врата за још неко југословенство и његове рецидиве, или можда треба рачунати на то да је анахрони термин српскохрватски и даље научни назив нашег језика, ${ }^{25}$ док термин српски треба да прихватимо за (просто)народски, разговорни и, мање-више, политички обележен? Заправо, врло смо близу овом последњем поимању ако у нашим највишим научним установама данас и даље истрајава термин српскохрватски (/ српско-хрватски), или, што је још парадоксалније, ако уз оживљен (у српској науци традиционалан) лингвистички термин српски језик и даље свесрдно негујемо паралелну употребу термина штокавски дијалекат, из једне посве другачије, разрушене „српскохрватске” научнополитичке парадигме.

Рационалистички принцип који исказује крилатица „правилно назвати значи правилно разумети" неговао се на Балкану још од антике, преко наших средњовековних исихаста (нпр. К. Филозофа), до Доситеја Обрадовића и Вука Караџића. Ваљда га савремена српска цивилизација неће изагнати из свог поимања света. То би за њу било још једно врло лоше знамење.

\section{ЦИТИРАНА ЛИТЕРАТУРА}

Будимир 1969: Милан Будимир, Са балканских источника, Српска књижевна задруга, Београд.

Добрашиновић 1995: Голуб Добрашиновић, Стојан Новаковић - Вуков следбеник, Стојан Новаковић - Личност и дело, Научни скуп поводом 150-годишњице рођења (1842-1992), Српска академија наука и уметности, Београд, 345-360.

JKL: Jugoslovenski književni leksikon (urednik Živan Milisavac), Matica srpska, Novi Sad 1971.

Кликовац / Николић 2014: Душка Кликовац, Љиљана Николић, Српски језик за први разред гимназија и средюих стручних икола, Eduka, Београд.

Kordić 2010: Snježana Kordić, Jezik i nacionalizam, Durieux, Zagreb.

Ломпар 2012: Весна Ломпар, Граматика. Српски језик и книжевност за први разред гимназија и средюих стручних школа, Klett, Београд.

У последњем речнику, после дуго времена, поново се јавио лингвоним српски (Речник српскога језика).

${ }^{25}$ На томе, чини се, и даље инсистира један број наших језикословаца, а међу страним овакав приступ се посебно негује на германском језичком поднебљу (в. Okuka 2006: 247, Kordić 2010: 132-136, исп. фус. 22). 
Marković 2005: Slobodan G. Marković, Srpske naučne ustanove u službi deifikacije jugoslovenskog diktatora (1), Hereticus, III/1, Beograd, 32-56.

Милосављевић / Суботић 2014: Петар Милосављевић, Момчило Суботић (прир.), О идентитету српског језика - О шездесетогодишьиии Новосадског договора, Матица српска у Дубровнику, Београд (Транскрипти са седница: 321-439).

Михаиловић 2006: Драгослав Михаиловић, Време за повратак, изд. Зоран Вацић и Драгослав Михаиловић, Београд.

Московљевић 1963: Милош С. Московљевић, О Речнику Српске академије наука, Зборник Матице српске за књижевност и језик, Књига једанаеста, Нови Сад, 240-252.

Okuka 2006: Miloš Okuka, Srpski na kriznom putu (Povjesnica, ideologija, jezička zbilja), Zavod za udžbenike i nastavna sredstva, Istočno Sarajevo.

Пипер 2016: Предраг Пипер, Српски језик као предмет језичког планирања, Зборник Института за српски језик САНУ, III, Српски језик и актуелна питања језичког планирања, Београд, 9-18.

Радић 2008: Првослав Радић, Дијалекат и норма у настави српског језика, Књижевност и језик, LV/1-2, Београд, 127-141.

Радић 2012: Првослав Радић, О лингвистици проф. Белића у светлу научнополитичких парадигми, Књижевност и језик, LIX/3-4, Београд, 181-201.

Ристић 2016: Стана Ристић, Штокавске збирке речи, http://www.politika. rs/scc/clanak/368166/Stokavske-zbirke-reci (20. XI 2016).

PCAНУ I: Речник српскохрватског књижевног и народног језика, књига I, $A-$ Богољуб, Српска академија наука, Институт за српскохрватски језик, Београд 1959 (с Уводом А. Белића, VII-XXVI).

Стијовић 2000: Рада Стијовић, Речник српскохрватског књижевног и народног језика САНУ и дијалекатска лексика, Јужнословенски филолог, LVI/3-4, Београд, 1121-1127. 
Prvoslav T. Radić

\title{
THE SO-CALLED GREAT DICTIONARY OF THE SERBIAN ACADEMY OF SCIENCES AND ARTS AND RELATED ISSUES
}

\author{
Summary
}

The first section of the paper deals with a terminological issue associated with Serb studies - it specifically discusses the place of the term "Shtokavian dialect" in Serb language studies. This is, in fact, one of the fundamental issues in Serb studies, though it arrives rather late on the agenda due to various complex circumstances. Without providing unambiguous answers to the question of the place and appropriateness of the term "Shtokavian" it is impossible to answer a whole series of related issues that are crucially important for Serb studies. These issues range from attempts to delimit the Serb linguistic area to the possible consistent use of the lynguonym Serb language (Serb. "srpski jezik") in modern language usage. Naturally, these questions are often associated with the interpretations of the titles of linguistic publications dealing with the Serb language, from both modern (e.g. Dictionary of the Serbian Academy of Sciences and Arts) and past times, and it is sometimes necessary to re-evaluate these linguistic terms. The second section of the paper is dedicated to this issue. 